\title{
Cross-functionality and innovation in new product development teams: A dilemmatic structure and its consequences for the management of diversity
}

\author{
Diether Gebert \\ Faculty of Economics and Management, Technical University Berlin, \\ Berlin, Germany \\ Sabine Boerner \\ Department of Politics and Management, University of Konstanz, \\ Konstanz, Germany \\ Eric Kearney \\ Faculty of Economics and Management, Technical University Berlin, \\ Berlin, Germany
}

The ubiquitous hope among managers of new product development (NPD) teams that a cross-functional team composition may be a royal road to enhancing team innovations appears to be an illusion. Empirical analyses show positive as well as negative or nonsignificant relationships between crossfunctionality and team innovations. In this article, we integrate the extant literature and develop a process model that explains the contradictory empirical findings. We propose that introducing specific mediators and moderators enables improved predictions of the effects of cross-functionality on team innovations. In developing our model, which is primarily based on a conflict-theoretical perspective, we address theories of social categorization, identity and self verification, information/decision making, group problem solving, and innovativeness, respectively. Our process model explicates how (i.e., via what mediators) and when (i.e., in the presence of what moderators) cross-functionality enhances or impedes synergistic communication among team members, which in turn fosters team innovations. On the basis of this new model we discuss strategies for managing cross-functionality in NPD teams.

Correspondence should be addressed to Diether Gebert, Faculty of Economics and Management, Technical University Berlin, Wilmersdorfer Str. 148, 10585 Berlin, Germany. E-mail: Diether.Gebert@tu-berlin.de 
Since the development of new products is of utmost importance for the competitiveness of companies, new product development teams (NPD teams) play a key role in securing organizational success (Katila \& Ahuja, 2002). It is still not clear, however, how the innovativeness of NPD teams can best be fostered and what role cross-functionality plays in this process (Jackson, Joshi, \& Erhardt, 2003). The widespread hope among practitioners that cross-functionality directly enhances team innovations is not supported by the empirical literature: studies that have examined this relationship have yielded inconsistent results (Jackson et al., 2003). Thus it is somewhat surprising that there exists no model that specifically and exclusively addresses the relationship between cross-functionality and the innovativeness of NPD teams. In order to bridge this gap in the literature, we have developed such a model by connecting these two variables on the basis of a broad overview of the extant literature and by positing specific mediators and moderators. We believe that this model enables a better understanding and prediction of how and under what conditions crossfunctionality holds promise with respect to team innovations. Moreover, our aim was to identify strategic measures that could be used in order to bring to fruition the innovative potential of functionally heterogeneous teams. Thus, our model can serve as the basis for informed further research and theory-guided practical steps.

Cross-functionality is defined as the degree to which team members differ concerning their functional backgrounds (Jackson, May, \& Whitney, 1995; Milliken \& Martins, 1996). Thus, cross-functionality (i.e., functional diversity) reflects the number of different functions (i.e., marketing, manufacturing, $R \& D$, etc.) that are represented within a team (Harrison $\&$ Klein, in press). Cross-functionality entails differences in regard to members' knowledge bases and experiential backgrounds (informational diversity; Jehn, Northcraft, \& Neale, 1999); moreover, cross-functionality is associated with differences concerning deep-seated beliefs, values, and attitudes (Jackson et al., 1995). (The latter differences constitute what Harrison, Price, \& Bell, 1998, call deep-level diversity.) We will show that not only the different knowledge bases and experiential backgrounds, but also the different attitudes and beliefs are important with respect to the innovation process in NPD teams. Cross-functionality is thus more taskrelated than is demographic diversity (Pelled, Eisenhardt, \& Xin, 1999). This serves as the frequently demanded (Lawrence, 1997; Pelled, 1996) rationale for why it is reasonable to choose cross-functionality as the one aspect among many (such as age, gender, etc.; see McGrath, Bordahl, \& Arrow, 1996) that reflect diversity within a team.

In theory, there are arguments for why cross-functionality should promote innovations in NPD teams. The innovativeness of new product development teams is usually defined and assessed by two criteria: firstly, the 
newness and usefulness of the technical solution; and, secondly, the adherence to time and budget constraints (Atuahene-Gima, 2003; Godener \& Söderquist, 2004). The members' different knowledge bases and experiential backgrounds increase a team's range of potentially useful ideas (Milliken \& Martins, 1996). Thus, cross-functionality facilitates the development of a new and productive technical problem solution (Bond, Walker, Hutt, \& Reingen, 2004). Moreover, in order to transfer a technical solution into a marketable product, it is important that different organizational divisions (e.g., R\&D, marketing, etc.) collaborate closely from the outset. If these functions are represented in NPD teams, this heightens the potential for improved coordination regarding task completion and constraint adherence (Brown \& Eisenhardt, 1995; Sheremata, 2000; Sicotte \& Langley, 2000; Thamhain, 2003).

While a positive relationship between cross-functionality and the innovations of NPD teams is thus to be expected, this expectation is not always confirmed empirically. Instead, a rather inconsistent picture emerges. In regard to the criterion of newness or creativeness of the technical solution as well as with respect to the criterion of constraint adherence, mainly nonsignificant relationships are reported in the literature (Keller, 2001; Lovelace, Shapiro, \& Weingart, 2001; Reagans \& Zuckerman, 2001; Webber \& Donahue, 2001; Williams \& O'Reilly, 1998). These nonsignificant correlations are sometimes positive and sometimes negative. This finding has led to the hypothesis that an increase in cross-functionality not only engenders positive effects on team innovations. Instead, it also spawns unplanned negative secondary effects in the form of communication and cooperation barriers within the team (Reagans \& Zuckerman, 2001). According to this hypothesis, the desired positive effects and the undesired negative effects of cross-functionality on team innovations neutralize each other, thus giving rise to correlations close to zero (Ancona \& Caldwell, 1992; Carroll \& Harrison, 1998; Reagans \& Zuckerman, 2001).

In order to facilitate an understanding of our arguments throughout this article, we will begin with an overview of our process model.

\section{A MODEL OF THE EFFECTS OF CROSS- FUNCTIONALITY ON TEAM INNOVATIONS}

Diversity management in NPD teams is of a dilemmatic nature: On the one hand, cross-functionality is needed for innovations; on the other hand, cross-functionality may obstruct cooperation and communication within the team. The desired primary effects of a cross-functional team composition are thus coupled with undesired secondary effects (Barry \& Bateman, 1996; Govindarajan \& Gupta, 2001). The assumed dilemmatic structure has important practical implications: A cross-functional team composition does 
not automatically translate into higher team innovativeness. Instead, a team leader must take into account that, in the absence of appropriate diversity management measures, the innovation-enhancing potential of high crossfunctionality will remain untapped, thus leaving the level of team innovations well below that which is possible. With respect to the effective management of cross-functionality in NPD teams, the important question is therefore if and to what degree undesired negative effects of crossfunctionality might be separable from desired effects. A more elaborated understanding of this dilemmatic structure is called for: How is a team's level of cross-functionality connected with desired and undesired effects on team innovations? In order to explore this question, we developed the process model depicted in Figure 1.

We posit that the innovativeness of an NPD team is the function of a specific quality of communication, which we call synergistic communication. We define synergistic communication as the extent to which members' diverging positions are specified and recombined to generate new and useful solutions. We assume that cross-functionality engenders interpretive differences and thus task conflicts (Jehn, 1995), which in turn serve as a catalyst for synergistic communication. In our model, task conflicts thus constitute an important mediator of the relationship between crossfunctionality and synergistic communication. However, task conflicts can be accompanied by negative effects, which can offset the positive effects: task conflicts are systematically connected with (undesired) relationship and value conflicts (Jehn, 1995), which impede the members' acceptance of divergent ideas and thus hamper synergistic communication in the team. Moreover, cross-functionality not only entails task conflicts, but also social categorizations (Hogg, Abrams, Otten, \& Hinkle, 2004) and consolidated diverging thought worlds (Dougherty, 1992), both of which can impair synergistic communication via relationship and value conflicts (Caldwell \& O'Reilly, 2003).

In considering these mediators, one could intuitively assume that a negative relationship between cross-functionality and team innovations should be more likely than a positive one. Nevertheless, since the development and relative strength of the desired and undesired effects are not known a priori, the effects of cross-functionality on team innovations can not be predicted solely on the basis of the above mediators. Therefore we have added to our model moderators that enable a more accurate prediction of the balance between the discussed positive and negative effects. For example, a common social identity will moderate the relationship between the desired task conflicts and the undesired relationship conflicts and value conflicts, respectively (Simons \& Peterson, 2000). A strong common social identity will foster a prevalence of the positive effects of task conflicts on synergistic communication over the 


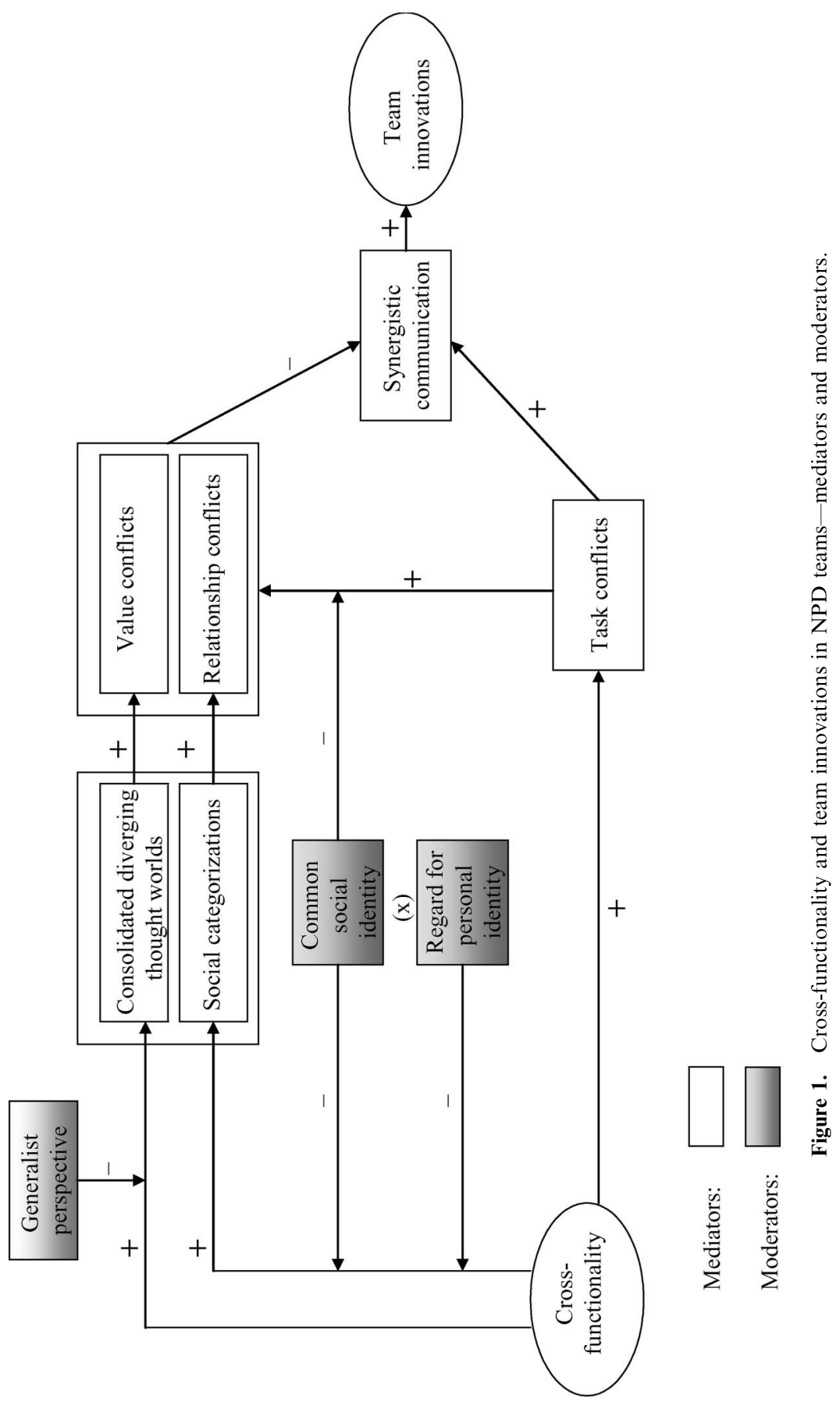


(indirectly transmitted) negative ones. Introducing moderators such as common social identity helps to shed some light on why empirical studies occasionally report negative associations between cross-functionality and team outcomes, while other studies find positive relationships (see also van der Vegt \& Bunderson, 2005, who focus on the moderator "collective team identification").

At the same time, moderators help to predict what balance between propitious and deleterious effects is likely to emerge in a given setting. They thus enable practical recommendations. For example, fostering a common social identity by establishing a win-win situation (outcome interdependence) (Schippers, Den Hartog, Koopman, \& Wienk, 2003) is a measure that can help to separate undesired mediators (relationship and value conflicts) from desired ones (task conflicts). Such measures can be used to defuse the dilemma outlined above. All the moderators specified in Figure 1 serve the purpose of attenuating the otherwise positive relationships between the undesired and the desired effects.

Our process model includes constructs from organizational and social psychology (transactive memory, confirmation bias, outcome interdependence). Moreover, it is based on theories of social categorization, identity, self-verification, information/decision making, group problem solving and innovation, respectively. When viewed in isolation, some of these theories (e.g., social categorization theory) posit negative effects and other theories (e.g., information/decision making) suggest positive effects of diversity on team innovations. Our primary focus, however, is a conflict-theoretical approach. By distinguishing task conflicts on the one hand and relationship conflicts and value conflicts on the other, this approach integrates the respective positive and negative effects posited by the above theories.

In sum, our process model yields an integrative explanation of the contradictions in the extant literature. By introducing specific moderators it enables reasonable predictions of when cross-functionality will have primarily positive or negative effects on team innovations. Furthermore, it offers theory-based concrete recommendations on how to defuse the dilemma outlined above. Compared to other models in the literature, we do not look at several different diversity variables or heterogeneity in general. Instead, we focus exclusively on functional diversity as an independent variable. We also do not examine team performance in general, but restrict ourselves to analysing team innovations as the dependent variable. By limiting our model to these variables, we aim to further our understanding of the effects of a clearly specified independent variable (cross-functionality) on a precisely demarcated dependent variable (team innovations) (Harrison \& Klein, in press).

In the following, we will first discuss the construct synergistic communication in more detail. We will then explain via which ("positive") paths 
cross-functionality enhances synergistic communication and via which ("negative") paths cross-functionality impairs synergistic communication.

\section{SYNERGISTIC COMMUNICATION AND TEAM INNOVATIONS}

In order to generate innovations, the knowledge and experiential bases of each team member must be activated and utilized by the team as a whole (Taggar, 2002), or else no positive synergy can be expected to result from the team process. We define positive synergy as a collectively developed group solution that is superior to the solution developed by the best individual in the team (Cooke \& Szumal, 1994; Michaelsen, Watson, \& Black, 1989). Thus, it is particularly important that the members' hitherto unshared object knowledge (i.e., the expert knowledge of, for example, the manufacturing specialist in the team) at least in part becomes a knowledge base that is shared by all team members (Wegner, 1987). Subsequently, new combinations of this knowledge merged with the knowledge that is already firmly established in the group can give rise to innovations (Okhuysen \& Eisenhardt, 2002).

Several empirical studies have shown, however, that this process of information sharing does not occur automatically (e.g., Brodbeck, Kerschreiter, Mojzisch, Frey, \& Schulz-Hardt, 2002; Stasser \& Titus, 1985). Instead of utilizing thus far unshared knowledge, team members exhibit a systematic tendency to primarily exchange and discuss object knowledge that is already shared among the team members. In order to realize vital exchanges and new combinations of ideas (elaboration in the sense of van Knippenberg, de Dreu, \& Homan, 2004), however, these elaboration processes of information exchange require a specific quality of communication in which innovations are fostered via the synergistic utilization of the full range of available abilities, skills, and perspectives. As mentioned above, we define synergistic communication as the extent to which diverging positions are specified and recombined to generate new and useful solutions. Instead of focusing on commonalities, it is therefore important to first specify dissent, i.e., to conduct critical reciprocal questioning (Mohammed \& Ringseis, 2001) and to foster debate concerning divergent views (Schneider, Smith, Taylor, \& Fleenor, 1998; Simons, Pelled, \& Smith, 1999). This tends to enhance the likelihood that unshared object knowledge, which is one component of "transactive memory" (Wegner, 1987), will be explicated. An explication of unshared object knowledge in turn generates meta-knowledge - the other component of transactive memory. Meta-knowledge entails that each team member knows what knowledge bases the other team members possess. This, in turn, makes it possible to direct questions at the right person (Brauner \& 
Becker, 2001) and facilitates the utilization of previously unshared object knowledge.

Proposition 1. Synergistic communication is positively related to team innovations.

Synergistic communication should be differentiated from the construct team reflexivity (West, 2000): Empirical studies show that the communication processes within a team are critical for team success (Keller, 2001; Lovelace, Shapiro, \& Weingart, 2001). A goal-oriented and well-coordinated innovation process requires that the team establishes a shared and valid task model and cooperation model (Edmondson, 1999; Gilson, Shalley, \& Milne, 2002; Mathieu, Goodwin, Heffner, Salas, \& Cannon-Bowers, 2000; Mohammed \& Ringseis, 2001). Based on this common understanding, the team can subsequently decide on which steps are to be taken in what order and how the workload should be distributed among team members. The process of team reflexivity (Schippers, Den Hartog, Koopman, \& Wienk, 2003; West, 2000) - defined as the overt reflection of objectives and team processes - can be interpreted as a continuous monitoring and adjustment of the established task and cooperation model. Such adjustments become particularly important when process conflicts (Jehn, Northcraft, \& Neale, 1999) arise, i.e., when team members differ with respect to the distribution of competencies and responsibilities within the team. Thus, team reflexivity can prevent process conflicts from escalating in a way that impairs synergistic communication. To the extent that team reflexivity directly monitors synergistic communication, the former fosters the latter.

\section{POSITIVE AND NEGATIVE EFFECTS OF CROSS- FUNCTIONALITY ON TEAM INNOVATIONS}

\section{The desired "path": Cross-functionality-task conflicts-synergistic communication}

Differences concerning members' knowledge bases and experiential backgrounds spawn so-called task conflicts (Pelled, Eisenhardt, \& Xin, 1999). Task conflicts are defined by the degree to which dissent has become manifest with respect to the appropriate route towards attaining an objective (Jehn, 1995; Jehn \& Mannix, 2001). An open task-related dissent is not a necessary condition for synergistic communication to occur (van Knippenberg et al., 2004). It can, however, serve as a trigger of synergistic communication (de Dreu \& Beersma, 2005; Edmondson, 1999; Klimoski \& Mohammed, 1994). We posit that task conflicts further synergistic communications by enhancing a level and an intensity of dissent specification that is conducive to generating 
novel solutions, at the same time militating against a dysfunctional level of harmony, a premature consensus, and a general atmosphere of groupthink. In order for task conflicts to promote synergistic communication, at least two conditions must be met: The team members must be sufficiently motivated and they must possess a sufficient level of task-related qualifications (van Knippenberg et al., 2004). We assume that these prerequisites are met in most NPD teams for the following reasons:

Specifying dissent makes it necessary for a person to present his or her position before the other team members. In doing so, however, the individual runs the risk that his or her view of the problem may deviate from the shared conceptions of the group and that his or her arguments may reveal weaknesses. We assume that members of NPD teams are particularly willing to take these risks. They are not only motivated extrinsically, but in large part also intrinsically in the sense of Amabile (1996). Due to the high complexity and newness of the problems they are to solve, they tend to identify with their tasks. This presumably enhances their willingness to voice their function-specific knowledge with the team.

Moreover, members of cross-functional NPD teams are likely to have or acquire a high level of task-related qualifications. According to Reagans and McEvily (2003), daily exposure to cross-functionality trains the team members to frame and convey their knowledge in such a way that it can be comprehended by other team members, despite small shared knowledge bases (Harrison, Price, \& Bell, 1998). Cross-functionality thus engenders a kind of training on the job and, with increasing practice, facilitates the knowledge exchange between representatives of different communities of practice (Reagans \& McEvily, 2003).

Proposition 2. Cross-functionality is positively related to task conflicts, which, in turn, are positively related to synergistic communication.

\section{The undesired "path" (1a): Task conflicts-relationship conflicts-synergistic communication}

A task conflict or cognitive conflict (Pelled, 1996) can be distinguished from a relationship conflict (de Dreu \& Beersma, 2005; Jehn, 1995; Jehn \& Mannix, 2001) or affective conflict (Pelled, 1996). In a task conflict, there are different opinions concerning the best way to attain specific goals. By contrast, a relationship conflict is not focused on the task. Instead, it ensues on the basis of emotional tensions among the group members and the experience of negative feelings.

One dilemmatic aspect in cross-functional teams is that relationship conflicts emerge alongside the desired task conflicts. Relationship conflicts 
are undesired, however, because they impede synergistic communication within the group. Several empirical studies have found a positive relationship between these two conflict types. For example, in their meta-analysis, de Dreu and Weingart (2003) report that, on average, task conflicts and relationship conflicts are positively correlated $(r=.54)$. Moreover, relationship conflicts are negatively correlated with the team members' job satisfaction $(r=-.56)$. It appears reasonable to assume that with decreasing satisfaction, the team members' openness for synergistic communication also decreases. Thus, there is no indication that cross-functionality automatically translates task conflicts (via synergistic communication) into team innovations. Instead, it seems likely that task conflicts are detrimental to synergistic communication when they emerge in conjunction with relationship conflicts (cf. Amason, 1996; de Dreu \& Weingart, 2003). This danger illustrates the challenge faced by leaders of cross-functional NPD teams: They have to separate the desired task conflicts from the undesired relationship conflicts.

In order to understand this undesired negative path (1a), it is important to examine why task conflicts are frequently combined with relationship conflicts and why relationship conflicts impede synergistic communication. First, task conflicts may spawn relationship conflicts, even when the team members strongly identify with the task. Open task-related dissent means that there is no social validation of one's own position. Team members may construe this as a questioning of their competencies and could thus feel threatened (Lazarus, 1991). If they link this threat that they perceive in a communication to the source of this communication, emotional tensions and relationship conflicts are likely to ensue among the team members (Simons \& Peterson, 2000). If this happens, task-related input from the source of this threat is less likely to be accepted.

Second, emotional tensions threaten to undermine team cohesion. To prevent this, the team may strive towards a consensus in the way described by Janis (1982) or via the (more narrowly defined) confirmation bias (Brodbeck et al., 2002; Schulz-Hardt, Frey, Lüthgens, \& Moscovici, 2000). The group then selectively seeks information that confirms existing opinions and preferences and thus fails to fully utilize the range of knowledge bases within its ranks (Frey, Schulz-Hardt, \& Stahlberg, 1996; Stasser \& Titus, 1985). Given the strong pressure towards group conformity (Jackson, 1965), the team members' willingness to voice dissenting views and accept members who espouse different positions is likely to decline (Cooke \& Szumal, 1994; Pelled et al., 1999).

This is the first undesired path that prevents the translation of crossfunctionality into positive innovation-related effects: Task conflicts can turn into relationship conflicts, which in turn impede synergistic communication (see Figure 1). This theoretical path serves to explain the empirically 
confirmed positive relationship between cross-functionality in NPD teams on the one hand and communication and cooperation barriers on the other (Ancona \& Caldwell, 1992; Keller, 2001; see also Hambrick, Li, Xin, \& Tsui, 2001; Knight et al., 1999).

\section{The undesired "path" (1b): Task conflicts-value conflicts-synergistic communication}

Task conflicts and relationship conflicts can each be distinguished from value conflicts (Jehn et al., 1999). While task conflicts pertain to dissent regarding the most appropriate way to pursue a goal, value conflicts ensue when the team members have different values and attitudes with respect to what the outcome of the group's efforts should be (e.g., effectiveness or efficiency). A value conflict exists, for example, when a team member wishes to technically optimize the product to be developed, while another team member primarily focuses on the product's usefulness from a customer's perspective and regards perfecting products as superfluous (Dougherty, 1996). Contrary to task conflicts, value conflicts involving goals and values are not based primarily on different experiences concerning certain methods and approaches. Rather, they reflect differences (in part due to socialization processes) with respect to the basic question of when the outcome of a completed work task is to be viewed as satisfactory.

Besides the frequent combination of task conflicts and relationship conflicts, a second aspect of the dilemmatic situation in cross-functional teams is that the desired task conflicts are often accompanied by undesired value conflicts (Jehn et al., 1999), which in turn impede synergistic communication. A rising frequency or a rising intensity of task-related dissent increases the danger that hitherto latent differences in members' values become manifest. When task conflicts are intense, value conflicts may be assumed to exist, even if objectively this is not the case. If team members feel that their professional identity is being questioned during a task conflict, this may lead them to assert their own identity forcefully (Schneider \& Northcraft, 1999). The result may be that value conflicts are not attenuated but increased and even expanded.

Jehn et al. (1999) have found that value conflicts exert negative effects on team outcomes. Lovelace et al. (2001) have confirmed these results in the context of NPD teams. These findings may be due to the impediments of synergistic communication that value conflicts engender. Value conflicts may obstruct the transformation of the initially explicated dissent into a consensus (Xie, Song, \& Stringfellow, 2003). Value conflicts not only reflect cognitive interpretive schemata, but also emotionally based values and attitudes acquired during the socialization process (Schneider et al., 1998). The more pronounced these values are, the more difficult it is for team 
members to regard preferences and views that differ from their own as justifiable and acceptable. Value conflicts thus jeopardize the preconditions for synergistic communication.

Proposition 3. Task conflicts are positively related to relationship conflicts and value conflicts, respectively, which in turn are both negatively related to synergistic communication.

\section{The undesired "path" (2a): Cross-functionality-social categorization processes - relationship conflicts}

As described above, cross-functionality translates into (undesired) relationship conflicts and value conflicts via (desired) task conflicts. Another negative effect of cross-functionality is that it enhances social categorization processes, which further primarily relationship conflicts, which in turn obstruct synergistic communication (Caldwell \& O'Reilly, 2003; Hogg, Abrams, Otten, \& Hinkle, 2004).

We distinguish between the following two kinds of social categorization.

Categorizing others as ingroup or outgroup members. Diversity implies dissimilarities among team members. Perceived dissimilarity causes problems in the long run if the perceived dissimilarity not only relates to surface-level diversity (e.g., age or gender), but also to deep-level diversity (e.g., attitudes and beliefs) (Harrison et al., 1998) and if these attitudes and beliefs are of central importance to a person's social identity (Chattopadhyay, Tluchowska, \& George, 2004; Leonard, Beauvais, \& Scholl, 1999; Lord, Brown, \& Freiberg, 1999). This is the case when the aspect in question is a central trait of the reference group through which a person defines himself or herself and upon which the person's social identity (Tajfel, 1981) is based. For example, a person who categorizes himself or herself as a passionate engineer views his or her professional peers as an important reference group.

Group members prefer to interact with and regard as attractive those persons whom they perceive as similar to themselves (Byrne, 1969). They ascribe an ingroup status to these similar others (Brewer, 1996) on the basis of specific characteristics (e.g., attire and appearance, verbal style, usage of technical terms). The group members thus seek to validate their own social identity (Tajfel, 1981). This is manifested in the empirical finding that in those teams whose members are dissimilar in regard to several characteristics, there is an increased likelihood of the formation of informal subgroups whose members are comparably similar to each other and dissimilar to the members of the other subgroups (Gibson \& Vermeulen, 2003; Lau \& Murnighan, 1998; Thatcher, Jehn, \& Zanutto, 
2003). Subsequently, the categorization of others as ingroup or outgroup members becomes more salient (Oakes, Turner, \& Haslam, 1991) and relationship conflicts among members of different subgroups are likely to arise.

The problem resulting from subgroup formation and higher levels of relationship conflicts within an NPD team is that to the degree that communication within subgroups improves, the communication between the subgroups deteriorates. Therefore, synergistic communication among the members of different (functional) subgroups within a larger NPD team will decline (Caldwell \& O'Reilly, 2003). (Qualifications of this assertion are discussed by Phillips, Mannix, Neale, \& Gruenfeld, 2004.)

Categorizing others as a prototype of a social category instead of as unique individuals. Regardless of whether social categorization processes lead to a more positive or a more negative view of others, the other person is not appreciated as a unique individual (Hogg \& Terry, 2000; Schneider et al., 1998). Since a person also strives to be respected in regard to his or her personal identity (Brewer, 1996; Brewer \& Brown, 1998), a person is likely to perceive it as a lack of recognition on the part of other team members if he or she feels that his or her identity is being reduced to a "prototype". As a consequence, ensuing relationship conflicts with these others will impair a person's willingness to support these other team members with innovationrelated input (Polzer, Milton, \& Swann, 2002). If the person feels stymied in expressing his or her individuality (Tajfel, 1981) and in validating his or her personal identity through actions (Swann, Polzer, Seyle, \& Ko, 2004), the innovation-related unshared knowledge of this person remains unknown and cannot be integrated into new combinations of ideas (Polzer et al., 2002). Thus, neglecting the individuality of team members can cause additional problems with regard to synergistic communication.

\section{The undesired "path" (2b): Cross-functionality-thought worlds-value conflicts}

Cross-functionality is not only characterized by differences regarding knowledge and experience. A certain organizational function also entails specific interpretive schemata that team members use to make sense of product innovations (Dougherty, 1992). Organizational functions (e.g., marketing, finance, strategic planning) differ with respect to their interpretive schemata, which Dougherty (1992) has called departmental thought worlds. These thought worlds enable a cognitive orientation concerning the assigned tasks. Dougherty (1992) has shown that in the context of product development, representatives of distinct organizational functions differ in regard to their thought worlds - that is, which aspects 
they view as relevant and decisive in a long-term perspective. They even differ with respect to what product development means to them.

Differences concerning team members' thought worlds impede synergistic communication if they become consolidated. Through function-specific socialization processes, the respective approach towards product development thus becomes a social norm. If being a member of a specific organizational function is relevant to one's identity, the pertinent thought world becomes part of a person's professional identity and is integrated into a complex system of personal beliefs.

With respect to the effects on synergistic communication, it is not the "cognitive distance" between members' different thought worlds that is crucial. Instead, most important are, firstly, the degree to which the thought worlds are connected with the team members' identity-constituting belief systems and, secondly, the extent to which these thought worlds have acquired the status of "truths" by having served as the basis for daily actions for prolonged periods of time. In the course of a function-specific socialization process, thought worlds can become increasingly consolidated and immutable. If different consolidated thought worlds collide, value conflicts (and, possibly, relationship conflicts as well) are likely to ensue, and it becomes less probable that the views of others will be regarded as justified and acceptable. "Thought worlds with different funds of knowledge cannot easily share ideas, and may view one another's central issues as esoteric, if not meaningless" (Dougherty, 1992, p. 182). Consequently, synergistic communication is impeded.

Proposition 4. Cross-functionality is positively related to social categorization processes and consolidated diverging thought worlds, both of which in turn impede synergistic communication.

\section{MODERATORS THAT CAN SERVE TO DEFUSE THE DILEMMA}

As outlined above, cross-functionality is directly and indirectly connected with both desired and undesired effects. This makes it difficult to predict how cross-functionality will affect team innovations in a given situation. In addition to the mediators specified above, our model comprises three moderators (see Figure 1). We posit that taking these moderators into account increases the accuracy of predictions concerning the relative strength of the positive and the negative effects of cross-functionality on team innovations. At the same time, we propose that these moderators constitute useful strategies for managing diversity.

By looking at the mediated relationships described in Figure 1, it becomes apparent at which junctions moderators are necessary. Firstly, what 
moderates the relationship between task conflicts on the one hand and relationship conflicts and value conflicts on the other? After having identified the moderator, what pertinent measures can be taken to separate the undesired relationship conflicts and value conflicts from the desired task conflicts? Secondly, what moderates the relationship between crossfunctionality on the one hand and social categorizations and consolidated diverging thought worlds on the other? And how can the undesired effects spawned by social categorizations and consolidated diverging thought worlds, respectively, be separated from cross-functionality?

Table 1 summarizes the moderators described below, as well as the managerial strategies based on these moderators.

\section{Problem 1: Separating task conflicts from relationship conflicts and value conflicts}

\section{Moderator: Common social identity}

The meta-analysis by de Dreu and Weingart (2003) indicates that task conflicts and relationship conflicts are separable in principle: Across different studies, the positive correlation between task conflicts and relationship conflicts varies between $r=.18$ and $r=.84$. Thus, the two conflict types are no Siamese twins, but covary depending on situational variables. While the likelihood that a task conflict will result in a

TABLE 1

Problems, moderators, and measures (managerial strategies)

\begin{tabular}{lll}
\hline Problem & Moderator & Measure \\
\hline $\begin{array}{l}\text { Separation of task } \\
\text { conflicts from } \\
\text { relationship conflicts } \\
\text { and value conflicts }\end{array}$ & $\begin{array}{c}\text { Common } \\
\text { social identity }\end{array}$ & $\begin{array}{l}\text { Structural: win-win } \\
\text { situation (outcome } \\
\text { interdependence) } \\
\text { Interactional: } \\
\text { (transformational) } \\
\text { leadership }\end{array}$ \\
$\begin{array}{l}\text { Separation of } \\
\text { cross-functionality } \\
\text { from social } \\
\text { categorizations }\end{array}$ & $\begin{array}{l}\text { see above } \\
\text { Enhancing the norm } \\
\text { "expression of } \\
\text { individuality benefits } \\
\text { team outcomes" }\end{array}$ \\
$\begin{array}{l}\text { Separation of } \\
\text { cross-functionality from } \\
\text { consolidated diverging } \\
\text { thought worlds }\end{array}$ & social identity & Regard for \\
\hline
\end{tabular}


relationship conflict may not be eliminated entirely, it can certainly be reduced (Simons \& Peterson, 2000).

We assume that establishing a common social identity in a team will moderate the relationship between these two types of conflicts. If there exists a common social identity, it is more likely that the team members will subjectively define the situation as cooperative and not as competitive (Alper, Tjosvold, \& Law, 2000), so that the otherwise substantial positive relationship between task conflicts on the one hand and relationship and value conflicts on the other becomes less pronounced (Simons \& Peterson, 2000; Tjosvold, 1986, 1997). Hence, it will be less likely that task-related dissent will lead to interpersonal tensions - or be misinterpreted as a personal attack - and that different ideas concerning the best way of attaining a goal (task-related dissent) will be construed as a manifestation of incompatible goals and values.

Moreover, perceiving and defining a situation as cooperative enhances the willingness to engage in team reflexivity (Schippers et al., 2003; Tjosvold, Hui, \& Yu, 2003; West, 2000). If team reflexivity is focused on the ever-present danger that task conflicts will turn into relationship and value conflicts (de Dreu \& Weingart, 2003), it can be used as a means to strive for a separation of the desired from the undesired conflict types. Thus, measures that contribute to the perception of the situation as cooperative as opposed to competitive serve to facilitate synergistic communication (Schippers et al., 2003), as Sethi and Nicholson (2001) have shown for NPD teams.

In principle, we see two possibilities of fostering a common social identity. The first is to establish a win-win situation, which is defined as a situation in which the gains of one person are commensurate with the other team members' gains (in contrast to a zero-sum game in which one person's gains are commensurate with another person's losses). Establishing outcome interdependence (Bettencourt, Brewer, Croak, \& Miller, 1992; Schippers et al., 2003) is a practical means suitable for installing a win-win situation. Under this condition, the team members "share a common destiny" (cf. Gaertner et al., 1999; Wageman, 1995, 2001). Outcome interdependence furthers the team members' willingness to cooperate and thus enhances innovation (Gaertner et al., 1999; Saavedra, Earley, \& van Dyne, 1993; Wageman, 2001).

Second, a common social identity can be promoted through interactional measures. This could be achieved through a leadership style that provides background information (McGrath, MacMillan, \& Venkatraman, 1995) and emphasizes a common vision and common objectives. Transformational leadership (Bass, 1998; Bass \& Avolio, 1994; Shamir, House, \& Arthur, 1993) appears to be particularly promising in this regard. If the team leader communicates and continually reiterates the team objectives in an inspiring 
way, these objectives can serve as the common ground for all team activities and become the basis of a shared social identity. Introducing symbolic demonstrations of team membership that help to distinguish the team from other teams, staging competitions between teams, and organizing social events for celebrating the attainment of partial goals may further enhance the development of a common social identity (Shamir et al., 1993). Moreover, it is essential that the team develops its own "history" (e.g., by overcoming crises that can only be overcome by the group as a whole) and shared recollections.

Proposition 5a. Common social identity moderates the relationship between task conflicts on the one hand and relationship conflicts and value conflicts on the other. If common social identity is high, the relationship between the desired and the undesired conflict types will be weaker than when common social identity is low.

\section{Problem 2a: Separating cross-functionality from social categorizations}

\section{Moderator: Common social identity}

Above, we identified categorizing others as ingroup or outgroup members and the resulting subgroup formation as one dysfunctional social categorization process. One of the negative effects of subgroup formation is that it enhances the development of relationship conflicts among members of the different subgroups and thus impedes synergistic communication. Establishing a common social identity (Tajfel, 1981) among team members may help prevent the formation of subgroups within cross-functional teams. The social categorization of another team member as similar or dissimilar must not necessarily depend on the other person's belonging to a certain profession or organizational function. If membership in the NPD team - as opposed to membership in a certain professional or functional category - is perceived as the salient ingroup criterion, the NPD team itself will become the basis for a common social identity (Gaertner, Dovidio, Mann, Murrell, \& Pomare, 1990; van Knippenberg \& Haslam, 2003).

Several studies show that subgroups cooperate with greater intensity and less discord when they share a common social identity (Chatman, Polzer, Barsade, \& Neale, 1998; Gaertner et al., 1999; Jehn \& Bezrukova, 2004; Kane, Argote, \& Levine, 2002). We proposed outcome interdependence (Schippers et al., 2003) - as a structural measure - and/or (transformational) leadership (Bass, 1998; Keller, 1992; Shamir et al., 1993) — as an interactional 
strategy - as expedient options for enhancing a common social identity, which in turn can facilitate the separation of functional effects from dysfunctional ones at two critical junctures (see Figure 1).

Proposition 5b. Common social identity moderates the relationship between cross-functionality and subgroup formation. If common social identity is high, this relationship is weaker than when common social identity is low.

\section{Moderator: Regard for personal identity}

Categorizing another person as a representative of a certain group instead of as a unique individual was the other dysfunctional categorization process we identified above. This type of categorization is problematic insofar as each team member is driven by two social motives: the need for inclusion and the need for differentiation (Brewer, 1996). Since developing a common social identity can restrict the opportunities for expressing individuality (Brewer \& Brown, 1998), it becomes important to simultaneously foster regard for personal identity.

Hence, it is vital to establish congruence between the self-view (i.e., the way a person perceives himself or herself) and the other team members' view of this person (Polzer et al., 2002; Swann et al., 2004). To promote this congruence, it is necessary that the individual can express himself or herself in all of his or her uniqueness, which in turn presupposes a social norm in which a divergence from the prototype (Hogg \& Terry, 2000) is welcomed (and not regarded as something to be avoided). Therefore, the team leader must emphasize that he or she not only sees great value in crossfunctionality, but also in the uniqueness of each individual (Ely \& Thomas, 2001; Polzer et al., 2002).

Proposition 5c. Regard for personal identity moderates the relationship between cross-functionality and the restriction of the expression of individuality. If regard for personal identity is high, this relationship will be weaker than when regard for personal identity is low.

While a common social identity can restrict personal identity, the reverse is also conceivable: Regard for personal identity can impede a common social identity (Brewer, 1996). Since, as described above, both facets of identity are important for synergistic communication, a concomitant enhancement of both social and personal identity appears to be most promising. We therefore posit an interaction effect of common social identity and regard for personal identity on the relationship between crossfunctionality and synergistic communication. (In order to keep Figure 1 as 
simple as possible, this interaction hypothesis is merely hinted at by an " $\mathrm{x}$ " in parentheses.)

Proposition 5d. In combination, common social identity and regard for personal identity moderate the relationship between cross-functionality and synergistic communication. If common social identity and regard for personal identity are high, this relationship will be stronger than when common social identity and regard for personal identity are low.

It merits consideration, however, that it will be difficult to stabilize such a double identity in larger collectives (e.g., an organizational division), because, for example, personnel fluctuation is likely to be higher. High turnover in large organizations will continually destabilize the common social identity (Brewer, 1996). By contrast, in an NPD team, being a much smaller unit, the development of a stable double identity should be easier.

In line with the interaction hypothesis (Proposition 5d), it is thus vital to use the above described structural and interactional measures (see Table 1) to facilitate a common social identity and, at the same time, to foster the norm that the expression of individuality is desired. Transformational leadership (Bass, 1998) appears to be particularly promising with respect to concomitantly enhancing a common social identity and a high regard for personal identity: Transformational leadership is a multidimensional construct; while the component "inspirational motivation" is likely to further a common social identity, the component "individualized consideration" is likely to promote regard for personal identity.

\section{Problem 2b: Separating cross-functionality from consolidated diverging thought worlds}

\section{Moderator: Generalist perspective}

As mentioned above, function-specific thought worlds, which result from function-specific socialization processes, may become consolidated by being incorporated as an essential component into the professional identity of a person. In order to undermine this consolidation process, which can hamper synergistic communication, it is vital to let each team member become acquainted with other thought worlds, for instance by introducing job rotation programs (Maruyama, 2004). Generalists trained in this or a similar way will have learned to distinguish and integrate different thought worlds (Gruenfeld \& Fan, 1999), which enables them to view a problem concerning product development more flexibly and holistically by taking into account 
several different thought world perspectives. In this sense, interdisciplinary courses at universities covering fields such as engineering, marketing, product design, manufacturing, etc. are commendable. Developing a generalist perspective within cross-functional NPD teams thus enhances the absorptive capacity (Cohen \& Levinthal, 1990; Zahra \& George, 2002) of the team members, i.e., their competencies regarding knowledge acquisition and knowledge transfer (Reagans \& McEvily, 2003), which in turn foster synergistic communication.

This argument sheds some light on the results reported by Bunderson and Sutcliffe (2002). In attempting to defuse the dilemma of managing crossfunctionality, they introduced a surprisingly simple strategy. According to Bunderson and Sutcliffe, cross-functionality must not necessarily be distributed across team members with different fields of specialization (socalled interpersonal cross-functionality). Instead, one could build a team of generalists in which each individual has sufficient cross-functional experience (so-called intrapersonal cross-functionality). According to these authors' findings, the exchange of information in top management teams is negatively related to interpersonal cross-functionality, but positively associated with intrapersonal cross-functionality. Thus, the facilitation of the average generalist-level in an NPD team is promising with respect to preventing the communication barriers (Dougherty, 1992) that impair synergistic communication.

Nevertheless, a drawback of the strategy of furthering the average generalist-level within the team is that it reduces the specialization benefits of transactive memory (Wegner, 1995). This results in a restricted range of ideas and a diminished potential for innovation-enhancing task-related dissent, while increasing the consensus potential. Thus, this measure does not eliminate, but can only defuse the dilemma inherent in diversity management.

Proposition 5e. The extent to which team members adopt a generalist perspective moderates the relationship between cross-functionality and consolidated diverging thought worlds. When generalist thinking is low, this relationship will be much stronger than when the generalist perspective is pronounced.

\section{CONCLUSION}

The widespread belief among practitioners that cross-functionality constitutes a sure path to team innovation appears to be unwarranted. Based on the premise that synergistic communication is a prerequisite for team innovations, our process model shows that cross-functionality is connected with different effects, some of which further and some of which hinder synergistic communication. Our model illustrates that cross-functionality 
does not automatically lead to team innovations. In order to obtain positive outcomes, an informed cross-functionality management is called for. According to our model, two aspects are of central importance. First, relationship conflicts and value conflicts, respectively, have to be separated from task conflicts. Second, social categorizations - which can lead to subgroup formation and may prevent the team members from expressing their individuality - as well as consolidated thought worlds - which can create communication barriers - need to be separated from cross-functionality. Without taking contextual conditions (moderators) into account, one should not expect a positive, but rather a nonsignificant association between cross-functionality and team innovations.

\section{Managerial implications}

Our model identifies three important moderators. First, we posited that fostering a common social identity is a sensible solution for separating desired types of conflict from undesired ones and for preventing dysfunctional social categorization processes. We outlined two managerial strategies for enhancing a common social identity: establishing outcome interdependence (a structural measure) and providing leadership that emphasizes common goals (an interactional measure). Second, we proposed that furthering regard for personal identity is a promising complementary managerial strategy. It thus appears sensible to establish the norm within the team that expressing individuality is conducive to the process of synergistic communication. Third, we suggested that promoting a generalist perspective can serve as a countermeasure against an increasing rigidity and immutability of the thought worlds entailed by different organizational functions. As a managerial strategy, it thus appears advisable to look for individuals who can bring a generalist's perspective to the group. At the same time, all team members should be trained in their ability to think "outside of the box" and adopt a generalist perspective. To this end, personnel development measures could include job rotation programmes.

\section{Theoretical implications}

Taking into account the moderators described in our model offers three distinct advantages. First, it enables explanations of why empirical studies yield inconsistent results concerning the association between cross-functionality and team innovativeness, with correlations ranging from positive to negative. Second, our model should lead to improved predictions with respect to when the positive or the negative effects of cross-functionality on team innovations are likely to be prevalent. Third, the discussed moderators 
enable the theory-based development of managerial strategies aimed at defusing the dilemma inherent in managing cross-functional teams.

A satisfactory explanation of the contradictory findings in the empirical literature requires the systematic integration of several different theoretical concepts (theories of social categorization, identity, conflicts, information processing, and group problem solving, respectively) and constructs from social and organizational psychology (confirmation bias, transactive memory, outcome interdependence), many of which have been viewed in isolation in prior research. The inconsistencies in the extant literature show that these theories and constructs are not by themselves able to adequately reflect the complexity of the relationship between cross-functionality and team innovations. Thus, we have attempted to integrate many of these theories and constructs into a coherent process model that specifies critical mediators and moderators.

In the attempt to predict team success, Pfeffer (1983) recommends focusing on the resources of the team and explicitly discourages the analysis of processes. By contrast, in the effort to explain the emergence of team innovations, our analysis underscores the importance of studying the interplay of processes and resources in cross-functional teams (cf. Taggar, 2002).

Our model is limited in that it contains some simplifications. For example, we have not elaborated on the possibility that under certain conditions social categorizations and consolidated thought worlds could also enhance desired task conflicts and, in turn, foster synergistic communication. Instead, we have focused on the primarily negative effects (i.e., relationship and value conflicts) of social categorizations and consolidated thought worlds on synergistic communication. Otherwise there would have been no need to introduce the moderators that are described in our model. In our view, focusing on these predominantly deleterious effects is well justified when considering the extant literature. For the sake of clarity and parsimony, we decided to focus on the strongest linkages. Nevertheless, alternative linkages between the described and additional mediators and moderators are possible and should be explored. While we believe that our model can serve as the backdrop for many important empirical analyses, it is, of course, only an approximation of a highly complex reality.

\section{REFERENCES}

Alper, S., Tjosvold, D., \& Law, K. S. (2000). Conflict management, efficacy and performance in organizational teams. Personnel Psychology, 53, 625-642.

Amabile, T. M. (1996). Creativity in context: Update to the social psychology of creativity. Boulder, CO: Westview Press.

Amason, A. C. (1996). Distinguishing the effects of functional and dysfunctional conflict on strategic decision making: Resolving a paradox for top management teams. Academy of Management Journal, 39, 123-148. 
Ancona, D. G., \& Caldwell, D. F. (1992). Demography and design: Predictors of new product team performance. Organization Science, 3, 321-341.

Atuahene-Gima, K. (2003). The effects of centrifugal and centripetal forces on product development speed and quality: How does problem solving matter? Academy of Management Journal, 46, 359-373.

Barry, B., \& Bateman, T. (1996). A social trap analysis of the management of diversity. Academy of Management Review, 21, 757-790.

Bass, B. M. (1998). Transformational leadership: Industry, military, and educational impact. Mahwah, NJ: Lawrence Erlbaum Associates, Inc.

Bass, B. M., \& Avolio, B. J. (1994). Improving organizational effectiveness through transformational leadership. Thousand Oaks, CA: Sage.

Bettencourt, B. A., Brewer, M. B., Croak, M. R., \& Miller, N. (1992). Cooperation and the reduction of intergroup bias: The role of reward structure and social orientation. Journal of Experimental Social Psychology, 28, 301-319.

Bond, E. U., Walker, B. A., Hutt, M. A., \& Reingen, P. H. (2004). Reputational effectiveness in cross-functional working relationships. Journal of Product Innovation Management, 21, $44-61$.

Brauner, E., \& Becker, A. (2001). Wormholes to organizational expertise: The management of meta-knowledge. In M. Crossan \& F. Olivera (Eds.), Organizational learning and knowledge management: New directions (pp. 31-48). London, ON: Richard Ivey School of Business.

Brewer, M. B. (1996). Managing diversity: Can we reap the benefits without paying the costs? In S. E. Jackson \& R. N. Ruderman (Eds.), Diversity in workteams: Paradigms for changing workplace (pp. 47-68). Washington, DC: American Psychological Association.

Brewer, M. B., \& Brown, R. J. (1998). Intergroup relations. In D. T. Gilbert, S. T. Fiske, \& G. Lindzey (Eds.), Handbook of social psychology (Vol. II, pp. 554-594). Boston: McGrawHill.

Brodbeck, F. C., Kerschreiter, R., Mojzisch, A., Frey, D., \& Schulz-Hardt, S. (2002). The dissemination of critical, unshared information in decision-making groups: The effects of pre-discussion dissent. European Journal of Social Psychology, 32, 35-56.

Brown, S. L., \& Eisenhardt, K. M. (1995). Product development: Past research, present findings, and future directions. Academy of Management Review, 20, 343-378.

Bunderson, J. S., \& Sutcliffe, K. M. (2002). Comparing alternative conceptualizations of functional diversity in management teams: Process and performance effects. Academy of Management Journal, 45, 875-893.

Byrne, D. (1969). Attitudes and attraction. In L. Berkowitz (Ed.), Advances in experimental social psychology (Vol. 4, pp. 35-89). New York: Academic Press.

Caldwell, D. F., \& O'Reilly, C. A. (2003). The determinants of team-based innovation in organizations: The role of social influence. Small Group Research, 34, 497-517.

Carroll, G. R., \& Harrison, J. R. (1998). Organizational demography and culture: Insights from a formal model and simulation. Administrative Science Quarterly, 43, 637-667.

Chatman, J. A., Polzer, J. T., Barsade, S. G., \& Neale, M. A. (1998). Being different yet feeling similar: The influence of demographic composition and organizational culture on work processes and outcomes. Administrative Science Quarterly, 43, 749-780.

Chattopadhyay, P., Tluchowska, M., \& George, E. (2004). Identifying the ingroup: A closer look at the influence of demographic dissimilarity on employee social identity. Academy of Management Review, 29, 180-202.

Cohen, W. M., \& Levinthal, D. A. (1990). Absorptive capacity: A new perspective on learning and innovation. Administrative Science Quarterly, 35, 128-152.

Cooke, R. A., \& Szumal, J. L. (1994). The impact of group interaction styles on problemsolving effectiveness. Journal of Applied Behavioral Science, 30, 415-437. 
De Dreu, C. K. W., \& Beersma, B. (2005). Conflict in organizations: Beyond effectiveness and performance. European Journal of Work and Organizational Psychology, 14, $105-117$.

De Dreu, C. K. W., \& Weingart, L. R. (2003). Task versus relationship conflict, team performance, and team member satisfaction: A meta-analysis. Journal of Applied Psychology, 88, $741-749$.

Dougherty, D. (1992). Interpretive barriers to successful product innovation in large firms. Organization Science, 3, 179-202.

Dougherty, D. (1996). Organizing for innovation. In S. R. Clegg, C. Hardy, \& W. R. Nord (Eds.), Handbook of organization studies (pp. 424-439). London: Sage.

Edmondson, A. C. (1999). Psychological safety and learning behavior in work teams. Administrative Science Quarterly, 44, 350-383.

Ely, R. J., \& Thomas, D. A. (2001). Cultural diversity at work: The effects of diversity perspectives on work group processes and outcomes. Administrative Science Quarterly, 46, $229-273$.

Frey, D., Schulz-Hardt, S., \& Stahlberg, D. (1996). Information seeking among individuals and groups and possible consequences for decision making in business and politics. In E. Witte \& J. H. Davis (Eds.), Understanding group behavior: Small group processes and interpersonal relations (pp. 211-227). Mahwah, NJ: Lawrence Erlbaum Associates, Inc.

Gaertner, S. L., Dovidio, J. F., Mann, J. A., Murrell, A. J., \& Pomare, M. (1990). How does cooperation reduce intergroup bias? Journal of Personality and Social Psychology, 59, $692-$ 704.

Gaertner, S. L., Dovidio, J. F., Rust, M. C., Nier, J. A., Banker, B. S., Ward, C. M., et al. (1999). Reducing intergroup bias: Elements of intergroup cooperation. Journal of Personality and Social Psychology, 76, 388-402.

Gibson, C., \& Vermeulen, F. (2003). A healthy divide: Subgroups as a stimulus for team learning behavior. Administrative Science Quarterly, 48, 202-239.

Gilson, L. L., Shalley, C. E., \& Milne, S. H. (2002). The critical role of creativity in the relationship between team processes and performance. Paper presented at the meeting of the Academy of Management, Denver, CO, USA.

Godener, A., \& Söderquist, K. E. (2004). Use and impact of performance measurement results in R\&D and NPD: An explanatory study. R\&D Management, 34, 191-220.

Govindarajan, V., \& Gupta, A. K. (2001). Building an effective global business team. MIT Sloan Management Review, 42, 63-71.

Gruenfeld, D. H., \& Fan, E. T. (1999). What newcomers see and what oldtimers say: Discontinuities in knowledge exchange. In L. L. Thompson, J. M. Levine, \& D. M. Messick (Eds.), Shared cognition in organizations: The management of knowledge (pp. 245-266). Mahwah, NJ: Lawrence Erlbaum Associates, Inc.

Hambrick, D. C., Li, J., Xin, K., \& Tsui, A. S. (2001). Compositional gaps and downward spirals in international joint venture management groups. Strategic Management Journal, $22,1033-1053$.

Harrison, D. A., \& Klein, K. J. (in press). What's the difference? Diversity constructs as separation, variety, or disparity in organizations. Academy of Management Review.

Harrison, D. A., Price, K. H., \& Bell, M. P. (1998). Beyond relational demography: Time and the effects of surface- and deep-level diversity on work group cohesion. Academy of Management Journal, 41, 96-107.

Hogg, M. A., Abrams, D., Otten, S., \& Hinkle, S. (2004). The social identity perspective: Intergroup relations, self-conception, and small groups. Small Group Research, 35, 246276.

Hogg, M. A., \& Terry, D. J. (2000). Social identity and self-categorization processes in organizational contexts. Academy of Management Review, 25, 121-140. 
Jackson, J. (1965). Structural characteristics of norms. In I. D. Steiner \& M. Fishbein (Eds.), Current studies in social psychology (pp. 301-309). New York: Holt, Rinehart, \& Winston.

Jackson, S. E., May, K. E., \& Whitney, K. (1995). Understanding the dynamics of diversity in decision-making teams. In R. A. Guzzo \& E. Salas (Eds.), Team effectiveness and decision making in organizations (pp. 204-261). San Francisco: Jossey-Bass.

Jackson, S. W., Joshi, A., \& Erhardt, N. L. (2003). Recent research on team and organizational diversity: SWOT analysis and implications. Journal of Management, 29, 801-830.

Janis, I. L. (1982). Groupthink. Boston: Houghton Mifflin.

Jehn, K. A. (1995). A multimethod examination of the benefit and detriments of intragroup conflict. Administrative Science Quarterly, 40, 256-282.

Jehn, K. A., \& Bezrukova, K. (2004). A field study of group diversity, workgroup context, and performance. Journal of Organizational Behavior, 25, 703-729.

Jehn, K. A., \& Mannix, E. A. (2001). The dynamic nature of conflict: A longitudinal study of intragroup conflict and group performance. Academy of Management Journal, 44, $238-251$.

Jehn, K. A., Northcraft, G. B., \& Neale, M. A. (1999). Why differences make a difference: A field study of diversity, conflict, and performance in workgroups. Administrative Science Quarterly, 44, 741-763.

Kane, A., Argote, L., \& Levine, J. M. (2002). Social identity and knowledge transfer between groups. Paper presented at the meeting of the Academy of Management, Denver, CO, USA.

Katila, R., \& Ahuja, G. (2002). Something old, something new: A longitudinal study of search behavior and new product introductions. Academy of Management Journal, 45, 1183-1194.

Keller, R. T. (1992). Transformational leadership and the performance of research and development project groups. Journal of Management, 18, 489-501.

Keller, R. T. (2001). Cross-functional project groups in research and new product development: Diversity, communications, job stress, and outcomes. Academy of Management Journal, 44, $547-555$.

Klimoski, R., \& Mohammed, S. (1994). Team mental model: Construct or metaphor? Journal of Management, 20, 403-437.

Knight, D., Pearce, C. L., Smith, K. G., Olian, J. D., Sims, H. P., Smith, K. A., \& Flood, P. (1999). Top management team diversity, group process, and strategic consensus. Strategic Management Journal, 20, 445-465.

Lau, D. C., \& Murnighan, J. K. (1998). Demographic diversity and faultlines: The compositional dynamics of organizational groups. Academy of Management Review, 23, $325-340$.

Lawrence, B. S. (1997). The black box of organizational demography. Organization Science, 8 , $1-22$.

Lazarus, R. S. (1991). Emotion and adaptation. New York: Oxford University Press.

Leonard, N. H., Beauvais, L. L., \& Scholl, R. W. (1999). Work motivation: The incorporation of self-concept-based processes. Human Relations, 52, 969-987.

Lord, R. G., Brown D. J., \& Freiberg, S. J. (1999). Understanding the dynamics of leadership: The role of follower self-concepts in the leader/follower relationship. Organizational Behavior and Human Decision Processes, 78, 167-203.

Lovelace, K., Shapiro, D. L., \& Weingart, L. R. (2001). Maximizing cross-functional new product teams' innovativeness and constraint adherence: A conflict communications perspective. Academy of Management Journal, 44, 779-793.

Maruyama, M. (2004). Polyocular vision or subunderstanding? Organization Studies, 25, $467-480$.

Mathieu, J. E., Goodwin, G. F., Heffner, T. S., Salas, E., \& Cannon-Bowers, A. (2000). The influence of shared mental models on team process and performance. Journal of Applied Psychology, 85, 273-283. 
McGrath, J. E., Bordahl, J. L., \& Arrow, H. (1996). Traits, expectations, culture, and clout: The dynamics of diversity in work groups. In S. Jackson \& M. Ruderman (Eds.), Diversity in work teams (pp. 17-45). Washington: APA Press.

McGrath, R. G., MacMillan, L. G., \& Venkatraman, S. (1995). Defining and developing competence: A strategic process paradigm. Strategic Management Journal, 16, 251-275.

Michaelsen, L. K., Watson, W. E., \& Black, R. H. (1989). A realistic test of individual versus group consensus decision making. Journal of Applied Psychology, 74, 834-839.

Milliken, F. J., \& Martins, L. L. (1996). Searching for common threads: Understanding the multiple effects of diversity in organizational groups. Academy of Management Review, 21, $402-433$.

Mohammed, S., \& Ringseis, E. (2001). Cognitive diversity and consensus in group decision making: The role of inputs, processes, and outcomes. Organizational Behavior and Human Decision Processes, 85, 310-335.

Oakes, P. J., Turner, J. C., \& Haslam, S. A. (1991). Perceiving people as group members: The role of fit in the salience of social categorizations. British Journal of Social Psychology, 30, $125-144$.

Okhuysen, G. A., \& Eisenhardt, K. M. (2002). Integrating knowledge in groups: How formal interventions enable flexibility. Organization Science, 13, 370-386.

Pelled, L. H. (1996). Demographic diversity, conflict, and work group outcomes: An interventing process theory. Organization Science, 7, 615-631.

Pelled, L. H., Eisenhardt, K. M., \& Xin, K. R. (1999). Exploring the black box: An analysis of group work diversity, conflict, and performance. Administrative Science Quarterly, 44, 1-28.

Pfeffer, J. (1983). Organizational demography. In L. L. Cummings \& B. M. Staw (Eds.), Research in organizational behavior (Vol. 5, pp. 299-357). Greenwich, CT: JAI Press.

Phillips, K. W., Mannix, E. A., Neale, M. A., \& Gruenfeld, D. H. (2004). Diverse groups and information sharing: The effects of congruent ties. Journal of Experimental Social Psychology, 40, 497-510.

Polzer, J. T., Milton, L. P., \& Swann, W. B., Jr. (2002). Capitalizing on diversity: Interpersonal congruence in small work groups. Administrative Science Quarterly, 47, 296-324.

Reagans, R., \& McEvily, B. (2003). Network structure and knowledge transfer: The effects of cohesion and range. Administrative Science Quarterly, 48, 240-267.

Reagans, R., \& Zuckerman, E. W. (2001). Networks, diversity, and productivity: The social capital of corporate R\&D teams. Organization Science, 12, 502-517.

Saavedra, R., Earley, P. C., \& van Dyne, L. (1993). Complex interdependence in taskperforming groups. Journal of Applied Psychology, 78, 61-72.

Schippers, M. C., Den Hartog, D. N., Koopman, P. L., \& Wienk, J. A. (2003). Diversity and team outcomes: The moderating effects of outcome interdependence and group longevity and the mediating effect of reflexivity. Journal of Organizational Behavior, 24(6), 779-802.

Schneider, B., Smith, D. B., Taylor, S., \& Fleenor, J. (1998). Personality and organizations: A test of the homogeneity of personality hypothesis. Journal of Applied Psychology, 83, $462-470$.

Schneider, S. K., \& Northcraft, G. B. (1999). Three social dilemmas of workforce diversity in organizations: A social identity perspective. Human Relations, 52, 1445-1467.

Schulz-Hardt, S., Frey, D., Lüthgens, C., \& Moscovici, S. (2000). Biased information search in group decision making. Journal of Personality and Social Psychology, 78, 655-669.

Sethi, R., \& Nicholson, C. Y. (2001). Structural and contextual correlates of charged behavior in product development teams. Journal of Product Innovation Management, 18, 154-168.

Shamir, B., House, R. J., \& Arthur, M. B. (1993). The motivational effects of charismatic leadership: A self-concept based theory. Organization Science, 4, 577-594.

Sheremata, W. A. (2000). Centrifugal and centripetal forces in radical new product development under time pressure. Academy of Management Review, 25, 398-408. 
Sicotte, H., \& Langley, A. (2000). Integration mechanisms and R\&D project performance. Journal of Engineering and Technology Management, 17, 1-37.

Simons, T., Pelled, L. H., \& Smith, K. A. (1999). Making use of difference: Diversity, debate, and decision comprehensiveness in top management teams. Academy of Management Journal, 42, 662-673.

Simons, T. L., \& Peterson, R. S. (2000). Task conflict and relationship conflict in top management teams: The pivotal role of intragroup trust. Journal of Applied Psychology, 85, $102-111$.

Stasser, G., \& Titus, W. (1985). Pooling of unshared information in group decision making: Biased information sampling during group discussion. Journal of Personality and Social Psychology, 48, 1467-1478.

Swann, W. B., Jr., Polzer, J. T., Seyle, D. C., \& Ko, S. J. (2004). Finding value in diversity: Verification of personal and social self-views in diverse groups. Academy of Management Review, 29, 9-27.

Taggar, S. (2002). Individual creativity and group ability to utilize individual creative resources: A multilevel model. Academy of Management Journal, 45, 315-330.

Tajfel, H. (1981). Human groups and social categories: Studies in social psychology. Cambridge, UK: Cambridge University Press.

Thamhain, H. J. (2003). Managing innovative R\&D teams. R\&D Management, 33, 297-311.

Thatcher, S. M. B., Jehn, K. A., \& Zanutto, E. (2003). Cracks in diversity research: The effects of diversity faultlines on conflict and performance. Group Decision and Negotiation, 12, 217-241.

Tjosvold, D. (1986). Constructive controversy: A key strategy for groups. Personnel, 63, 39-44.

Tjosvold, D. (1997). Conflict within interdependence: Its value for productivity and individuality. In C. K. W. de Dreu \& E. van de Vliert (Eds.), Using conflict in organizations (pp. 39-52). London: Sage.

Tjosvold, D., Hui, C., \& Yu, Z. (2003). Conflict management and task reflexivity for team inrole and extra-role performance in China. International Journal of Conflict Management, 14, $141-163$.

Van der Vegt, G., \& Bunderson, J. S. (2005). Learning and performance in multidisciplinary teams: The importance of collective team identification. Academy of Management Journal, $48,532-547$.

Van Knippenberg, D., de Dreu, C. K. W., \& Homan, A. C. (2004). Work group diversity and group performance: An integrative model and research agenda. Journal of Applied Psychology, 89, 1008-1022.

Van Knippenberg, D., \& Haslam, S. A. (2003). Realizing the diversity dividend: Exploring the subtle interplay between identity, ideology and reality. In S. A. Haslam, D. van Knippenberg, M. Platow, \& N. Ellemers (Eds.), Social identity at work: Developing theory for organizational practice (pp. 205-221). New York: Taylor \& Francis.

Wageman, R. (1995). Interdependence and group effectiveness. Administrative Science Quarterly, 40, 145-180.

Wageman, R. (2001). How leaders foster self-managing team effectiveness: Design choices versus hands-on coaching. Organization Science, 12, 559-577.

Webber, S. S., \& Donahue, L. M. (2001). Impact of highly and less job-related diversity on work group cohesion and performance: A meta-analysis. Journal of Management, 27, 141-162.

Wegner, D. M. (1987). Transactive memory: A contemporary analysis of the group mind. In B. Mullen \& G. R. Goethals (Eds.), Theories of group behavior (pp. 185-208). New York: Springer.

Wegner, D. M. (1995). A computer network model of human transactive memory. Social Cognition, 13, 319-339.

West, M. A. (2000). Reflexivity, revolution, and innovation in work teams. Advances in Interdisciplinary Studies of Work Teams, 5, 1-29. 
Williams, K. Y., \& O’Reilly, C. A. (1998). Demography and diversity in organizations: A review of 40 years of research. Research in Organizational Behavior, 20, 77-140.

Xie, J., Song, M., \& Stringfellow, A. (2003). Antecedents and consequences of goal incongruity on new product development in five countries: A marketing view. Journal of Product Innovation Management, 20, 233-250.

Zahra, S. A., \& George, G. (2002). Absorptive capacity: A review, reconceptualization, and extension. Academy of Management Review, 27, 185-203.

Manuscript received December 2005 Revised manuscript received May 2006 First published online 27 July 2006 